\title{
PENGARUH PENERAPAN LKPD BERBASIS INKUIRI TERBIMBING DI MAN 1 KOTA BIMA
}

\author{
Nurfidianty Annafi \\ Progam Pendidikan Kimia \\ Sekolah Tinggi Ilmu Pendidikan Bima \\ nurfidianty89@gmail.com
}

\begin{abstract}
This research aims to determine: (1) The difference in study result of knowledge between experimental class and control class. (2) The difference of scientific attitude between experimental class and control class. (3) The level of adherence to the syntax of the experimental class guided inquiry. Methods used true experimental design. Samples to this research are students of class XI IPA 1 as control class and the students in class XI IPA 2 as experiment class of MAN 1 City of Bima The instrument that used in this study were interview, validation sheets, questionnaires, tests, and observation. Data were analyzed using qualitative descriptive analysis. Learning outcomes of knowledge was measured using a normalized gain (N-Gain). Gain Score was then analyzed using SPSS 18. Ratings scientific attitude of students were analyzed using Permendikbud votes No.81A 2013. While the syntax implemetation ratings were analyzed using descriptive analysis qualitatively by determining the percentage of sub variables. The results showed that: (1) The mean of $\mathrm{N}$-Gain in study result of knowledge experimental class was higher than control class. (2) Ratings scientific attitude of students class experiment shows the category of "EXCELLENT", while the control group showed the category of "GOOD". And (3) Syntax implementation of guided inquiry in the experimental class showed the category of "EXCELLENT".
\end{abstract}

Keywords: Guided Inquiry, Study Result of Knowledge, Scientific Attitude

\begin{abstract}
Abstrak
Penelitian ini bertujuan untuk mengkaj perbedaani: (1) hasil belajar pengetahuan antara kelas eksperimen dan kelas kontrol. (2) sikap ilmiah antara kelas eksperimen dan kelas kontrol. (3) Tingkat keterlaksanaan sintaks inkuiri terbimbing kelas eksperimen. Desain penelitian yang digunakan adalah eksperimen penuh. Sampel pada penelitian ini adalah peserta didik kelas XI IPA 1 sebagai kelas kontrol dan peserta didik kelas XI IPA 2 MAN 1 Kota Bima sebagai kelas eksperimen. Instrumen yang digunakan dalam penelitian ini terdiri dari: pedoman wawancara, lembar validasi, angket, tes, dan lembar observasi. Teknik analisis data menggunakan analisis deskriptif secara kualitatif dan kuanlitatif. Hasil belajar pengetahuan peserta didik diukur menggunakan normalized gain (N-Gain). Nilai Gain Score ternormalisasi tersebut kemudian dianalisis menggunakan SPSS 18. Penilaian sikap ilmiah peserta didik dianalisis menggunakan penilaian Permendikbud No.81A Tahun 2013. Sedangkan penilaian keterlaksanaan sintaks dianalisis menggunakan analisis secara deskriptif kualitatif dan kuantitatif dengan menentukan persentase sub variabel. Berdasarkan hasil penelitian, dapat disimpulakan: (1) Rata-rata perolehan $\mathrm{N}$-Gain hasil belajar pengetahuan peserta didik kelas eksperimen lebih tinggi dibanding kelas kontrol. (2) Penilaian sikap ilmiah peserta didik kelas eksperimen menunjukkan kategori "SANGAT BAIK", sedangkan kelas kontrol menunjukkan kategori "BAIK”. Dan (3) Keterlaksanaan sintaks inkuiri terbimbing pada kelas eksperimen menunjukkan kategori "SANGAT BAIK”.
\end{abstract}

Kata Kunci: Inkuiri Terbimbing, Hasil Belajar Pengetahuan, Sikap Ilmiah 


\section{PENDAHULUAN}

Kimia merupakan pembelajaran yang penting dan menarik karena ilmu kimia berkaitan dengan segala yang ada dihadapan manusia, baik itu pakaian yang dikenakan, udara yang dihirup, makanan yang dimakan, bahan bakar untuk memasak, dan lain sebagainya. Sehingga beberapa ilmuwan mengatakan bahwa kehidupan adalah kimia dan tak ada kehidupan tanpa kimia. Kimia adalah salah satu rumpun IPA yang membahas kajian mengenai materi dan energi dan interaksi antara keduanya (Goldberg, 2007). Materi tersebut adalah segala sesuatu yang memiliki wujud dan menempati ruang.

Kemenarikan pengetahuan kimia tidak dibarengi oleh antusiasme dan semangat peserta didik dalam pembelajaran kimia di sekolah. Akibatnya pembelajaran kimia dianggap sulit bagi kebanyakan peserta didik. Materi termokimia salah satunya. Termokimia merupakan ilmu yang mempelajari perubahan kalor yang menyertai reaksi kimia (Chang, 2004). Kesulitan peserta didik mempelajari materi termokimia tercermin dari rendahnya perolehan hasil Ujian Nasional tahun 2013 dan 2014 di Kota Bima pada materi Termokimia dapat dilihat pada Tabel 1.1 berikut.

Tabel 1.1 Persentase Penguasaan Materi Soal Kimia Ujian Nasional pada Materi Termokimia

\begin{tabular}{llll}
\hline Tahun & Kabupaten & Propinsi & Nasional \\
\hline 2013 & 41,49 & 56,79 & 67,76 \\
2014 & 36,07 & 43,76 & 41,86
\end{tabular}

(Depdiknas, 2013 dan 2014)

Persentase penguasaan materi termokimia peserta didik di Kota Bima menduduki tingkat paling rendah di antara materi kimia lainnya yang diujiankan, artinya daya serap peserta didik terhadap materi termokimia sangat kurang. Bahkan berdasarkan data pada tabel 1.1 menunjukkan bahwa terjadi penurunan persentase penguasaan materi termokimia dari tahun 2013 ke tahun 2014. Berdasarkan hasil observasi di MAN 1 Kota Bima, peserta didik masih terbiasa dengan bantuan dari guru untuk menyelesaikan tugas-tugas dan kegiatan pembelajarannya. Aktifitas peserta didik menjadi kurang sehingga peserta didik kurang antusias dalam kegiatan belajar mengajar.

Pada hakikatnya, pembelajaran kimia di sekolah diarahkan agar peserta didik memperoleh pengalaman menarik melalui kegiatan menemukan sendiri konsep pengetahuan sehingga pengetahuan yang diperoleh dapat bertahan lama pada ingatannya. Dan dalam mempelajari materi termokimia, dibutuhkan fakta-fakta untuk mempelajari konsep perubahan kalor. Namun pada kenyataannya dalam pembelajarannya peserta didik jarang diarahkan untuk berinkuiri. Materi termokimia disajikan dalam bentuk yang instan artinya materi diberikan langsung tanpa menghadirkan kegiatan mengamati fakta-fakta kimia. Kegiatan mengamati ini penting di terapkan dalam pembelajaran untuk menimbulkan rasa ingin tahu dari peserta didik.

Untuk memberikan ruang yang cukup bagi peserta didik dalam belajar, guru membutuhkan bahan ajar seperti Lembar Kegiatan Peserta Didik (LKPD). LKPD berbasis inkuiri terbimbing merupakan salah satu pilihan bahan ajar yang tepat karena dapat mengarahkan peserta didik menemukan sendiri konsep pengetahuannya. LKPD berbasis inkuri terbimbing yang digunakan mengandung unsur pengalaman belajar pokok yang diamanatkan oleh kurikulum 2013 yaitu mengamati, menanya, mengumpulkan informasi, mengasosiasi dan mengkomunikasikan.

Menurut Silver, at al (2007) bahwa pembelajaran inkuiri merupakan model pembelajaran yang mempunyai pengaruh yang kuat dan efektif digunakan dalam pembelajaran karena peserta didik diberikan kesempatan untuk belajar secara kompleks. Hasil penelitian terdahulu yang dilakukan oleh Vlasi M \& Karalioka (2012) yang bertujuan untuk membandingkan motode inkuiri terbimbing dengan metode tradisional menunjukkan hasil bahwa terjadi peningkatan hasil belajar yang signifikan dari pembelajaran dengan metode inkuiri terbimbing.

Kehadiran LKPD berbasis inkuiri terbimbing dapat membantu guru untuk menciptakan ketertiban peserta didik dalam menemukan dan menyusun konsep dengan proses yang sistematis. Menurut Darmodjo dan Kaligis (1993) LKPD adalah salah satu media yang digunakan untuk mengoptimalkan keterlibatan atau aktivitas peserta didik dalam pembelajaran.

Berdasarkan uraian tersebut, maka dalam penelitian ini peneliti mengangkat tema "Penerapan LKPD Berbasis Inkuiri Terbimbing pada Materi Termokimia Di MAN 1 Kota 
Bima”. Adapun tujuan dari penelitian ini adalah untuk mengetahui: (1) Perbedaan hasil belajar pengetahuan antara kelas eksperimen dan kelas kontrol. (2) Perbedaan sikap ilmiah antara kelas eksperimen dan kelas kontrol. (3) Tingkat keterlaksanaan sintaks inkuiri terbimbing kelas eksperimen.

Sedangkan hipotesis penelitian ini adalah terdapat perbedaan yang nyata antara nilai ratarata kelas eksperimen dan nilai rata-rata kelas kelompok control.

\section{METODE PENELITIAN}

Jenis penelitian yang digunakan pada penelitian ini adalah penelitian eksperimen penuh atau quasi experimental design. Pengambilan sampel dilakuan dengan tekhnik nonequivevalent control group design karena kelas eksperimen maupun kelas kontrol tidak dipilih secara random.

Sampel pada penelitian ini adalah peserta didik kelas XI IPA 1 sebagai kelas kontrol dan peserta didik kelas XI IPA 2 MAN 1 Kota Bima sebagai kelas eksperimen. Instrumen yang digunakan dalam penelitian ini terdiri dari: tes hasil belajar, (pretest dan post-test) angket sikap dan lembar observasi keterlaksanaan sintaks.

Instrumen hasil belajar pengetahuan terlebih dahulu di lakukan uji coba untuk mengetahui tingkat validitas dan reliabilitas, daya beda dan tingkat kesukarannya. Kemudian soal tes tersebut dapat diberikan kepada kelas eksperimen dan kelas kontrol dalam bentuk pretest dan postest untuk mengetahuai keadaan awal dan akhir setelah diberi perlakuan. Dengan demikian hasil perlakuan dapat diketahui lebih akurat, karena dapat membandingkan keadaan sebelum dan sesudah diberi perlakuan (Sugiyono, 2010)

Tabel 1.2 Desain penelitian

\begin{tabular}{ccc}
\hline $\mathrm{O}_{1}$ & $\mathrm{X}$ & $\mathrm{O}_{2}$ \\
\hline $\mathrm{O}_{3}$ & & $\mathrm{O}_{4}$ \\
\hline
\end{tabular}

Keterangan:

(Sugiyono, 2010)

$\mathrm{O}_{1}=$ pretest pada kelas eksperimen

$\mathrm{O}_{2}=$ posttest pada kelas eksperimen

$\mathrm{X}=$ treatment berupa pembelajaran menggunakan LKPD berbasis inkuiri terbimbing

$\mathrm{O}_{3}=$ pretest pada kelas kontrol

$\mathrm{O}_{4}=$ posttest pada kelas kontrol
Teknik analisis data menggunakan analisis deskriptif kualitatif. Penilaian hasil belajar pengetahuan peserta didik menggunakan penskoran yaitu, setiap soal diberi skor 1 jika benar, dan 0 jika salah. Skor yang diperoleh peserta didik adalah jumlah jawaban yang benar sedangkan skor kriteria adalah jumlah total skor seluruh soal. Penilaian hasil belajar pengetahuan untuk suatu perangkat tes pilihan ganda berupa perolehan skor (Ps) skala 4 yang dihitung dengan rumus:

$$
P s=\frac{\text { skor yang diperoleh }}{\text { skor kriteria }} \times 4
$$

Skor kriteria adalah jumlah butir soal dikali skor maksimal. Hasil perolehan skor peserta didik kemudian ditabulasi kedalam kategori penilaian menurut Permendikbud No 81A Tahun 2013 yang dapat dilihat pada Tabel 1.3 .

Tabel 1.3 Kategori Penilaian Hasil Belajar

\begin{tabular}{cc}
\hline Perolehan Skor $(\mathrm{Ps})$ & Kategori Penilaian \\
\hline $3,33<\mathrm{Ps} \leq 4,00$ & Sangat Baik (SB) \\
$2,33<\mathrm{Ps} \leq 3,33$ & Baik (B) \\
$1,33<\mathrm{Ps} \leq 2,33$ & Cukup (C) \\
Ps $\leq 1,33$ & Kurang (K) \\
\hline
\end{tabular}

Untuk mengetahui adanya peningkatan hasil belajar pengetahuan peserta didik antara kelas kontrol dan kelas eksperimen digunakan analisis normalized gain atau sering disebut gain score. Gain score ternormalisasi menurut Hake (1999) dapat digunakan dengan rumus berikut:

$$
<g>=\frac{\text { skor postes }- \text { skor pretes }}{\text { skor maksimal }- \text { skor pretes }}
$$

Keterangan:

$\langle\mathrm{g}\rangle=$ gain ternormalisasi .

Tabel 1.4 Kriteria Nilai Gain Score Ternormalisasi

\begin{tabular}{cc}
\hline Nilai $\langle\mathrm{g}\rangle$ & Kriteria \\
\hline$\langle\mathrm{g}>\geq 0,7$ & Tinggi \\
$0,7<\mathrm{g}>\geq 0,3$ & Sedang \\
$\langle\mathrm{g}><0,3$ & Rendah \\
\hline
\end{tabular}

Nilai Gain Score ternormalisasi tersebut kemudian dianalisis menggunakan SPSS 18. Uji normalitas dan homogenitas dilakukan untuk mengetahui jenis uji T yang akan digunakan, uji $\mathrm{T}$ parametrik atau non parametrik.

Statistik uji yang dipilih menggunakan kolmogorov-smirnov untuk uji normalitas dan Levene-Test untuk uji homogenitas dengan taraf signifikansi $(\alpha)=0,05$. Kriteria uji : Jika $\operatorname{Sig} \geq$ 0,05 , Ho diterima dan jika Sig < 0,05, Ho ditolak (Yamin, $2011: 45$ ) 
Data yang diperoleh dalam penelitian diolah dengan menguji kesamaan rata-rata yang digunakan adalah uji-t dengan ketentuan sebagai berikut:

(1) Hipotesis Penelitian

Ho = Tidak ada perbedaan nilai rata-rata kelas eksperimen dan nilai rata-rata kelas kontrol

$\mathrm{H}_{1}=$ Terdapat perbedaan yang nyata antara nilai rata-rata kelas eksperimen dan nilai rata-rata kelas kontrol

(2) Hipotesis Statistik

$\mathrm{Ho}=\delta_{1}^{2} \neq \delta_{2}^{2}$

$\mathrm{H}_{1}=\delta_{1}^{2} \neq \delta_{2}^{2}$

(3) Statistik uji yang dipilih menggunakan independent sample $t$-test

(4) Taraf signifikansi $(\alpha)=0,05$

(5) Kriteria pengujian

Jika Sig. (2-tailed) < 0,05, Ho ditolak

Jika Sig. (2-tailed) $\geq 0,05$, Ho diterima

Penilaian sikap ilmiah peserta didik menggunakan angket yang dimuat dalam bentuk tabel skor skala Likert 1-4.

$1=$ kurang baik

$2=$ Cukup baik

$3=$ Baik

4 = Sangat Baik (Riduwan, 2008)

Hasil penilaian tersebut kemudian ditabulasi kedalam kategori penilaian menurut Permendikbut No.81A Tahun 2013 yang terdapat pada Tabel 1.3.

Sedangkan penilaian keterlaksanaan sintaks dimuat dalam bentuk skor nilai, dengan rentang nilai yang digunakan adalah antara 0-2. Jika jawaban YA maka diberi skor 2, dan jika jawaban KURANG diberi skor 1, dan jika jawaban TIDAK diberi skor 0 , kemudian dianalisis menggunakan analisis secara deskriptif kualitatif dengan menentukan persentase sub variabel.

$$
\text { Ps }(\%)=\frac{\text { Jumlah skor hasil pengumpulan data }}{\text { skor kriteria }} \times 100 \%
$$

Skor kriteria $=$ skor tertinggi $\mathrm{x}$ jumlah aspek

Keterangan:

Ps $=$ Persentase sub variabe

\section{HASIL DAN PEMBAHASAN}

Hasil
Dalam pembahasan ini, ada tiga hal utama yang akan dibahas sesuai dengan tujuan penelitian ini yaitu mengetahui: (1) Perbedaan hasil belajar pengetahuan antara kelas eksperimen dan kelas kontrol. (2) Perbedaan sikap ilmiah antara kelas eksperimen dan kelas kontrol. (3) Tingkat keterlaksanaan sintaks inkuiri terbimbing kelas eksperimen.

1. Hasil belajar pengetahuan antara kelas eksperimen dan kelas control

Instrumen tes hasil belajar pengetahuan sebelumnya di uji cobakan terlebih dahulu kepada kelas yang telah menerima materi Termokimia (kelas XII IPA 1) untuk mengetahui validitas, reliabilitas, tingkat kesukaran dan daya pembeda butir-butir soal yang disusun. Berdasarkan hasil analisis menggunakan program ANATES, dari 25 butir soal yang disusun terdapat 5 butir soal yang dinyatakan gugur.

Tabel 1.5 Analisis hasil uji coba instrumen tes

\begin{tabular}{ccc}
\hline Butir Soal & Tingkat Kesukaran & Daya Beda \\
\hline 5 & Sangat Mudah & Jelek \\
11 & Sangat Mudah & Sangat Jelek \\
18 & Sangat Sukar & Jelek \\
20 & Sangat Sukar & Sangat Jelek \\
22 & Sangat Sukar & Sangat Jelek \\
\hline
\end{tabular}

Berdasarkan kriteria tersebut, maka 5 butir soal yang dinyatakan gugur tersebut dibuang dan 20 butir soal lainnya digunakan untuk mengukur hasil belajar pengetahuan peserta didik kelas eksperimen dan kelas kontrol. Pretest dan postest diberikan kepada masing-masing kelas untuk mengetahui skor $\mathrm{N}$-Gain.

Tabel 1.6 Data Hasil Belajar Pengetahuan Peserta Didik MAN 1 Kota Bima

\begin{tabular}{cccccc}
\hline \multirow{2}{*}{ No. } & \multirow{2}{*}{ Kelas } & \multicolumn{2}{c}{ Rerata } & \multirow{2}{*}{ N-Gain } & \multirow{2}{*}{ Kategori } \\
\cline { 3 - 4 } & & Pre-test & Post-test & & \\
\hline 1. & Kontrol & 0,96 & 2,65 & 0,55 & Tinggi \\
\hline 2. & Eksperimen & 0,90 & 2,94 & 0,7 & Sedang \\
\hline
\end{tabular}

Analisis selanjutnya menggunakan SPSS menunjukkan bahwa data berdistribusi normal dan homogen yaitu dengan sig. $\geq 0,05$ yang disajikan pada tabel berikut.

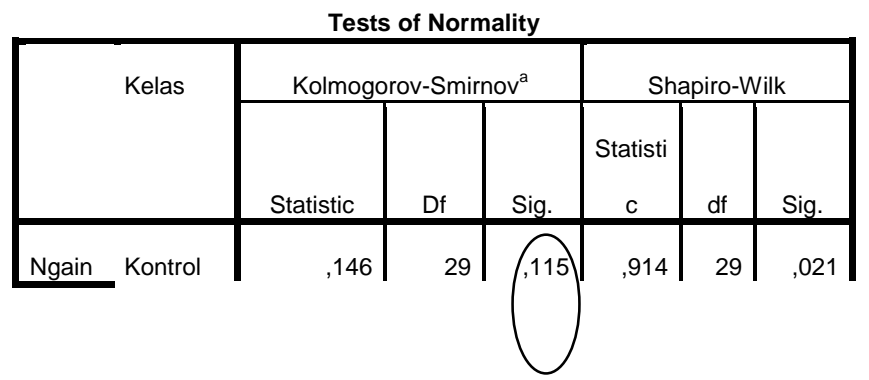




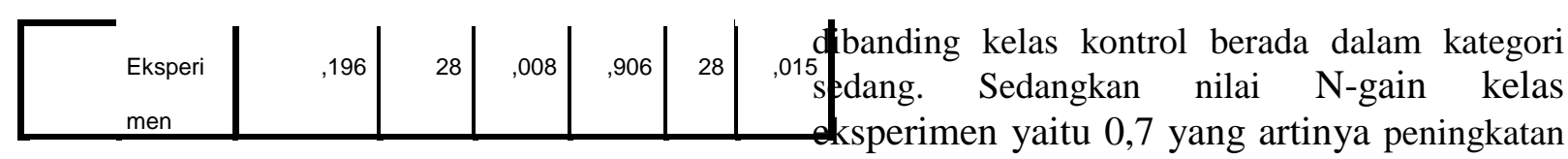

a. Lilliefors Significance Correction hasil belajar yang lebih dibanding kelas eksperimen berada dalam kategori tinggi.

Test of Homogeneity of Variance

\begin{tabular}{|c|r|r|r|r|}
\hline & $\begin{array}{r}\text { Levene } \\
\text { Statistic }\end{array}$ & df1 & \multicolumn{1}{|c|}{ df2 } & Sig. \\
\hline Ngain $\quad$ Based on Mean &, 224 & 1 & 55 & \\
&, 068 & 1 & 55 &, 795 \\
Based on Median &, 068 & 1 & 51,573 &, 795 \\
Based on Median & & & & \\
and with adjusted df &, 173 & 1 & 55 &, 679 \\
Based on trimmed & & & & \\
mean & & & & \\
\hline
\end{tabular}

Karena data dinyatakan berdistribusi normal dan homogen maka uji $\mathrm{T}$ yang digunakan yaitu uji $\mathrm{T}$ parametrik dengan statistik uji yang dipilih menggunakan independent sample t-test. Kesimpulan analisis uji menggunakan SPSS dapat dilihat pada tabel 1.7 berikut.

Tabel 1.7. Kesimpulan Data Uji T

\begin{tabular}{lccl}
\hline \multirow{2}{*}{ Jenis Uji } & \multicolumn{2}{c}{ Sig } & \multirow{2}{*}{$\begin{array}{c}\text { Kesimpulan } \\
\text { Data }\end{array}$} \\
\cline { 2 - 3 } & $\begin{array}{c}\text { Kelas } \\
\text { Kontrol }\end{array}$ & $\begin{array}{c}\text { Kelas } \\
\text { Eksperimen }\end{array}$ & \\
\hline Normalitas & 0,115 & 0,008 & Normal \\
\hline Homogenitas & 0,638 & Homogen \\
\hline Uji T & 0,093 & Tidak ada beda \\
\hline
\end{tabular}

Berdasarkan data tersebut, diketahui bahwa tidak ada perbedan nilai rata-rata kelas eksperimen dan nilai rata-rata kelas kontrol. Secara signifikan memang tidak terlihat perbedaan hasil belajar. Namun, jika merujuk pada data dalam tabel 1.5, nilai rerata posttest kelas eksperimen lebih tinggi dibandingkan kelas kontrol meskipun nilai rerata pretest kelas kontrol sedikit lebih tinggi dibanding kelas eksperimen. Hal ini menunjukkan bahwa peserta didik kelas eksperimen memiliki antusias yang baik dalam pembelajaran menggunakan LKPD berbasis inkuiri terbimbing sehingga ada peningkatan hasil belajar yang lebih dibanding kelas kontrol yang ditunjukkan oleh nilai normalized gain (N-Gain) atau sering disebut gain score.

Nilai N-gain kelas kontrol yaitu 0,55 yang artinya peningkatan hasil belajar yang lebih
2. Sikap ilmiah antara kelas eksperimen dan kelas control

Kelas eksperimen dan kelas kontrol mempunyai perolehan skor yang berbeda. Pada tabel 1.8 ditayangkan data sikap ilmiah peserta didik. Dimana perolehan skor rata-rata kelas eksperimen lebih tinggi dibanding skor rata-rata kelas kontrol. Hal ini menunjukkan bahwa ratarata sikap ilmiah kelas eksperimen lebih baik dibandingkan kelas kontrol. Kelas eksperimen memperoleh kategori sangat baik, sedangkan kategori penilaian kelas kontrol yaitu baik.

Tabel 1.8 Data Sikap Ilmiah Peserta Didik MAN 1 Kota Bima

\begin{tabular}{cccc}
\hline No. & Kelas & $\begin{array}{c}\text { Skor rata- } \\
\text { rata }\end{array}$ & Katagori \\
\hline 1. & Kontrol & 2,92 & Baik \\
2. & Eksperimen & 3,34 & Sangat Baik \\
\hline
\end{tabular}

Berdasarkan data tersebut, diketahui bahwa Penilaian sikap ilmiah terdiri dari 8 komponen, diantaranya yaitu jujur, teliti, tanggung jawab, disiplin, ingin tahu, menghargai, kritis dan kerja sama. Hasil penilaian setiap komponen sikap ilmiah peserta didik ditunjukkan oleh tabel 1.9 berikut.

Tabel 1.9 Skor masing-masing komponen sikap ilmiah kelas eksperimen dan kontrol

\begin{tabular}{|c|c|c|c|c|c|}
\hline \multirow[b]{2}{*}{ No. } & \multirow{2}{*}{$\begin{array}{l}\text { Komponen } \\
\text { Sikap Ilmiah }\end{array}$} & \multirow{2}{*}{$\begin{array}{c}\text { Nomor } \\
\text { Butir } \\
\text { Soal }\end{array}$} & \multicolumn{2}{|c|}{ Rerata } & \multirow[b]{2}{*}{ Selisih } \\
\hline & & & Kontrol & Eksperimen & \\
\hline 1 & Jujur & 1,2 & 3,33 & 3,43 & 0,10 \\
\hline 2 & Teliti & 3 & 3,40 & 3,70 & 0,30 \\
\hline 3 & $\begin{array}{l}\text { Tanggung } \\
\text { Jawab }\end{array}$ & 4,5 & 3,14 & 3,34 & 0,20 \\
\hline 4 & Disiplin & $6,7,8,9$ & 2,72 & 2,88 & 0,16 \\
\hline 5 & Ingin Tahu & 10,11 & 2,66 & 3,16 & 0,50 \\
\hline 6 & Menghargai & 12 & 3,80 & 3,90 & 0,10 \\
\hline 7 & Kritis & 13,14 & 2,76 & 3,57 & 0,81 \\
\hline 8 & Kerjasama & 15 & 3,70 & 4,00 & 0,30 \\
\hline
\end{tabular}

Tabel 1.9 diatas menggambarkan bahwa sikap ilmiah seperti jujur, teliti, tanggung jawab, disiplin, ingin tahu, menghargai, kritis, dan kerjasama dapat ditingkatkan melalui pembelajaran inkuiri terbimbing. Perbedaan yang signifikan terdapat pada komponen kritis dan rasa ingin tahu. Dimana skor sikap kritis kelas eksperimen 0,81 lebih tinggi dibanding kelas 
eksperimen, dan skor rasa ingin tahu peserta didik kelas eksperimen 0,50 lebih tinggi dibanding kelas kontrol.

\section{Tingkat keterlaksanaan sintaks inkuiri terbimbing \\ Hasil observasi keterlaksaan sintaks disajikan pada Tabel. 1.10 berikut.}

Tabel 1.10 Hasil Pengamatan Keterlaksanaan Sintaks Inkuiri Terbimbing

\begin{tabular}{lccc} 
& Pertemuan ke- & Ps (\%) & Kategori \\
\cline { 2 - 4 } Aktivitas & 1 & 71,43 & B \\
Guru & 2 & 85,71 & SB \\
& 3 & 100 & SB \\
\hline Rerata & & $\mathbf{8 5 , 7 1}$ & SB \\
\hline Aktivitas & 1 & 75 & B \\
Peserta Didik & 2 & 83,33 & SB \\
& 3 & 100 & SB \\
\hline Rerata & & $\mathbf{8 6 , 1 1}$ & SB \\
\hline
\end{tabular}

Tabel diatas menunjukkan bahwa aktivitas guru dan peserta didik kelas eksperimen mempunyai kategori penilaian "sangat baik", artinya LKPD berbasis inkuri terbimbing diterapkan dengan kategori penilaian sangat baik. Dan dari pertemuan ke- I sampai pertemuan keIII, aktifitas guru dan peserta didik selalu menunjukkan peningkatan. Hal ini menunjukkan bahwa sintaks inkuiri terbimbing terlaksana dengan sangat baik di MAN 1 Kota Bima.

Kegiatan observasi terhadap keterlaksanaan sintaks inkuiri terbimbing tersebut dilakukan untuk mengetahui sejauh mana penggunaan LKPD berbasis inkuri terbimbing dapat diterapkan dalam pembelajaran dan sejauh mana peserta didik dapat mengimplementasikan pembelajaran dengan metode inkuiri terbimbing.

\section{Pembahasan}

Keadaan tersebut tidak terlepas dari pengaruh penggunaan model inkuiri terbimbing yang terintegrasi dalam LKPD pada kelas eksperimen yang menuntut peserta didik belajar secara aktif dalam kerja kelompok.

Brunner cit. Dahar (2006) menyimpulkan bahwa penerapan model pembelajaran inkuiri memiliki kelebihan tertentu diantaranya yaitu dapat melatih keterampilan-keterampilan kognitif peserta didik untuk menemukan dan memecahkan masalah tanpa pertolongan orang lain. Menurutnya, belajar penemuan sesuai dengan pencarian pengetahuan secara aktif oleh manusia dan dengan sendirinya memberikan hasil yang paling baik, karena 1) pengetahuan itu bertahan lama atau lama diingat atau lebih mudah diingat bila dibandingkan dengan pengetahuan yang dipelajari dengan cara-cara lain; 2) hasil belajar penemuan mempunyai efek transfer yang lebih baik daripada hasil belajar lainnya; 3) secara menyeluruh belajar penemuan meningkatkan penalaran peserta didik dan kemampuan untuk berpikir secara bebas.

Tentang sikap ilmiah kelas kelompok eksperimen dan kontrol dapat diberi alasan karena peserta didik kelas eksperimen menggunakan pembelajaran inkuiri terbimbing yang menuntun peserta didik melakukan penyelidikan untuk memperoleh dan mendapatkan informasi melalui eksperimen untuk mencari jawaban atau memecahkan masalah dengan menggunakan kemampuan berpikir kritis dan logis. Sehingga peserta didik mempunyai rasa ingin tahu yang tinggi dan sikap kritis muncul. Dipertegas oleh Joyce \& Weil (2000) yang menyatakan bahwa inkuri terbimbing menggunakan cara pengumpulan informasi yang relevan dan menggunakan analisis logis melalui penyelidikan, serta investigasi fenomena sekitar dengan petunjuk berupa pertanyaan membimbing, sehingga peserta didik menyelesaikan permasalahan berdasarkan fakta yang ditemukan.

Konsep yang ditemukan peserta didik melalui pengalaman belajar mereka sendiri, membuat peserta didik lebih antusias dan terbiasa dengan metode pembelajaran yang digunakan. Berdasarkan ciri-ciri pembelajaran inkuiri terbimbing, peserta didik mampu membangung konsep pengetahuannya melalui pengalaman belajarnya sendiri. Ciri-ciri tersebut yaitu 1) peserta didik belajar dengan aktif dan memikirkan sesuatu berdasarkan pengalaman; 2) peserta didik aktif membangun pengetahuannya; 3) peserta didik mengembangkan daya pikir yang lebih tinggi melalui petunjuk atau bimbingan yang disediakan; 4: perkembangan peserta didik terjadi pada serangkaian tahapan; 6) peserta didik belajar melalui interaksi sosial dengan peserta didik lainnya (Kuhlthau, 2006)

\section{SIMPULAN DAN SARAN}

Berdasarkan hasil analisis data dan
pembahasan yang telah dilakukan dapat
disimpulkan:

1. Pembelajaran menggunakan LKPD berbasis inkuiri terbimbing pada materi Termokimia 
dapat meningkatkan hasil belajar pengetahuan. Rerata peningkatan hasil belajar pengetahuan peserta didik kelas eksperimen lebih tinggi dibanding rerata peningkatan hasil belajar pengetahuan peserta didik kelas kontrol.

2. Pembelajaran menggunakan LKPD berbasis inkuiri terbimbing pada materi Termokimia dapat meningkatkan sikap ilmiah peserta didik. Penilaian sikap ilmiah peserta didik kelas eksperimen menunjukkan kategori "SANGAT BAIK", sedangkan kelas kontrol menunjukkan kategori "BAIK".

3. Keterlaksanaan sintaks inkuiri terbimbing pada kelas eksperimen menunjukkan kategori "SANGAT BAIK".

Berdasarkan kesimpulan dan pembahasan sebelumnya, berikut ini beberapa saran yang diharapkan :

1) Kepada guru diharapkan agar menerapkan model pembelajaran inkuiri terbimbing untuk mendorong peserta didik berpikir kritis.

2) Diharapkan hasil penelitian ini dapat digunakan sebagai acuan oleh peneliti lain untuk penelitian berikutnya yang sejenis dengan materi yang berbeda.

\section{DAFTAR RUJUKAN}

Chang, R. 2005. Kimia Dasar Konsep-konsep Inti Edisi Ketiga. Jakarta: Erlangga.

Dahar, R. W. 2006. Teori-teori Belajar \& Pembelajaran. Jakarta : Erlangga

Darmodjo, H dan Kaligis, J. R. E. 1993. Pendidikan IPA II. Jakarta: Dirjen Dikti

Depdiknas. 2013. Laporan Hasil Ujian Nasional Tahun 2012-2013 (versi aplikasi). Jakarta: Depdiknas

Depdiknas. 2014. Laporan Hasil Ujian Nasional Tahun 2012-2013 (versi aplikasi). Jakarta: Depdiknas

Goldberg, D. E. 2007. Kimia Untuk Pemula. Jakarta : Erlangga

Hake, R. R. 1998. Interactive-engangement vs traditional methods: a six-thosand-student survey of mechanics test data for intruductory physics courses. American Journal of Physics, 66(1), 64-74

Joyce, B and Marsha Weil, M. 2000. Model of Teaching. Boston: Allyn and Bacon

Kuhlthau, C. 2006. Guided Inquiry: Learning in the 21st Century. New York: Libraries Unlimited.
Permendikbud. 2013. Permendikbud Nomor $81 \mathrm{~A}$ Tahun 2013 tentang Implementasi Kurikulum

Riduwan. 2008. Skala Pengukuran Variabelvariabel Penelitian. Bandung: Alfabeta.

Silver, C. E. H., Duncan, R. G., Chinn, C. A., 2007. Scafoalding and achievement in Problem-Based and Inquiry Learning: A Responses to Kirschner, Sweller, and Clark (2006). Educatonal Psychologist. 42(2), 99 - 107

Sugiyono. 2010. Metode Penelitian Pendidikan Pendekatan Kuantitatif, Kualitatif, dan R \& D. Bandung: Alfabeta

Vlasi M. dan Karaliota, A. 2013. The Comparison between Guided Inquiry and Traditional Teaching Method. A Case Study for the Teaching of the Structure of Matter to 8 th Grade Greck Student. Social and Behavioral Science. 93: 494497.

Yamin, M. 2011. Paradigma Baru Pembelajaran. Jakarta: Gaung Pustaka 